\title{
Q1 New occurrences and biological aspects to four species of rodents (Mammalia: Cricetidae) from Brazil
}

Felipe Santana Machado ${ }^{1}$

Ivan Junqueira Lima²

Arina Pacheco Magalhães Lopes ${ }^{3}$

Aloysio Souza de Moura ${ }^{4}$

Thamíris Christina Karlovic de Abreu ${ }^{5}$

\section{Abstract}

The most representative group among mammals are rodents for presenting high ratio to the total of species. However, rodents are considered a "taxonomic chaos" and some species such as Blarinomys breviceps, Bibimys labiosus, Akodon lindberghi and Pseudoryzomys simplex are little known. That can be explained because of low occurrence of small terrestrial mammals in wildlife inventories and/or reduced abundance. The objective is to describe the occurrence of these species and analyze these locations presenting descriptive comments about their biological aspects. Therefore, in addition to specimens collected in the field, some scientific collections were visited and reviews in relevant literature were conducted in order to obtain information about the locations and biological aspects. Akodon lindberghi was found in five sites, Bibimys labiosus was found in 15, Blarinomys breviceps in 39 and Pseudoryzomys simplex in 13. Each species has specific information and they are included in two threatened areas, Atlantic Forest and Cerrado. The occurrences are disconnected and related to taxonomic and methodological problems.

Keywords: New records. Rodentia. Sigmodontinae. Occurence area.

\section{Introduction}

The group of mammals from Brazil has been recently compiled by Paglia et al. (2012), presenting 701 mammalian species. The most representative group of mammals is the sigmodontine rodents, representing $34.7 \%$ of all diversity compiled. On average, as mentioned by Patterson (2000), scientists described a new genus and eight new species each year.

Despite the representativeness, the group of rodents is considered a "taxonomic chaos". Taxonomic information and natural history are disjoint affairs. Specialists are compelled to gather a lot of books and articles to collect the necessary information to fully understand the group. Recently, some efforts to systematize these information generated unprecedented papers. Among them, we can men-

1 Universidade Federal de Lavras - UFLA, Departamento de Ciências Florestais - DCF, Doutorando. epilefsama@hotmail.com. PO Box 3037, Zip Code: 37200-000, Lavras, MG, Brazil. Corresponding author.

2 Instituto de Desenvolvimento Sustentável Mamirauá, pesquisador (mestrando). ivanjunqueirabio@gmail.com. Estrada do Bexiga, 2.584, Bairro Fonte, PO Box 38, Zip Code: 69.553-225, Tefé, AM, Brazil. \& Instituto Nacional de Pesquisas da Amazônia. Av. André Araújo, 2.936 - Petrópolis - Manaus - AM, Brasil. PO Box 2223 - CEP 69080-971.

3 Instituto Nacional do Câncer - INCA, mestranda. arinabioufla@gmail.com. Av. Brasil, 4365 - Manguinhos, Zip Code: 21040-900, Rio de Janeiro, RJ, Brazil.

4 Universidade Federal de Lavras - UFLA, Departamento de Ciências Florestais - DCF, pesquisador associado. thraupidaelo@yahoo.com.br. PO Box 3037, Zip Code: 37200-000, Lavras, MG, Brazil.

5 Universidade Federal de Lavras - UFLA, Departamento de Biologia - DBI, mestranda. thamycka@hotmail.com. P0 Box 3037, Zip Code: 37200-000, Lavras, MG, Brazil. 
tion the taxonomic keys (which are vital for understanding biodiversity) in Bonvicino et al. (2008), Weksler and Percequillo (2011) and Patton et al. (2015). Even so, some groups are poorly known. De Vivo (2007) mentions that these problems are a result of the small number of taxonomists, repulse in sacrificing and collecting specimens for scientific collections, preparation of material in wet and dry way in the wrong form, lack of source from material, problems in identification and the method not being appropriate to capture certain groups.

Besides these problems, some species still present low occurrence in small terrestrial mammal wildlife inventories and/or low abundance. These species are considered rare for this paper. The species Blarinomys breviceps and Bibimys labiosus began to be caught more frequently in the late 1990s by increasing the use of pitfall traps (Silva et al., 2003). Akodon lindberghi was commonly mistaken for young animals of the same genus due to its small size (Gonçalves et al., 2005). Finally, Pseudoryzomys simplex has not been typically captured by conventional methods such as tomahawks, Sherman traps and pitfall traps (commonly recorded by owl regurgitation - TALAMONI et al., 2000; PARDIÑAS et al., 2004; TETA et al., 2009; TETA; PARDIÑAS, 2010).

Then, targeting the relevant problematic understanding of that group, the objectives were to show new localities of occurrence of Blarinomys breviceps, Bibimys labiosus, Akodon lindberghi and Pseudoryzomys simplex; describe their geographic distributions and, additionally, present comments on its biological aspects.

\section{Material and methods}

\section{Specimen collection and sites of occurrence}

Individuals were collected from June 2009 to April 2010 in five sites that comprised two stretches of semi deciduous forest (one at 1,300 $\mathrm{m}$ and the other at 1,400 $\mathrm{m}$ high), one of natural grassland (at 1,500 $\mathrm{m}$ ) and two at cloud forests (at 1,550 m) in the "Chapada das Perdizes" $\left(21^{\circ}\right.$ 35'S 443' W), located between the cities of Minduri and Carrancas (Minas Gerais state, Brazil). At each of these locations, different types of live-traps were installed: Shermann ${ }^{\circledR}$, Tomahawk ${ }^{\circledR}$ and pitfall. Individuals were collected through license of IBAMA - ICMBio (permanent license 185282) and deposited at the Coleção de Mamíferos da Universidade Federal de Lavras (CMUFLA). The material consisted of skins, skulls and carcasses preserved on alcohol $70 \%$. All the proceedings of capture, manipulation, collection and preservation of material followed the protocol of Sikes et al. (2011).

Specimens deposited in scientific collections and data from the literature were used (Tables 1, 2, 3 and 4). The collections visited were: Coleção de Mamíferos da UFLA (CMUFLA), Museu de Zoologia da Unicamp (ZUEC), Laboratório de Diversidade e Conservação de Mamíferos da Universidade de São Paulo (DICOM/USP) and Laboratório de Ecologia e Conservação de Mamíferos da UFLA (LECOM/UFLA). The vegetation type of each location is presented according to the literature or registration in Tombo book/identification card (Livro de Registo/Livro de Tombo in Portuguese).

The specimens were identified based on morphological description according to Bonvicino et al. (2008), Matson and Abravaya (1977), Silva et al. (2003), Hershkovitz (1990), Gonçalves et al. (2005), Gonçalves et al. (2007) and Voss and Myers (1991). 


\section{Results}

The known geographic distribution of $A$. lindberghi comprises the state of Minas Gerais and Distrito Federal with only five sites of occurrence (Figure 1 ). The sites are located in Cerrado, Atlantic Forest and the ecotonal zone between both domains. The altitude in which $A$. lindberghi appeared varied from 550 to $1,500 \mathrm{~m}$. Table 1 contains information about the areas.

Table 1. Akodon lindberghi records in Brazil. The number of each report corresponds to the localities representation on Figure 1.

\begin{tabular}{|c|c|c|}
\hline Localities (with coordinates) & Vegetation type & Reference \\
\hline $\begin{array}{l}\text { 1. Carrancas/Minduri, Mata } \\
\text { Triste, MG } \\
21^{\circ} 35^{\prime} 37^{\prime \prime S} 44^{\circ} 33^{\prime} 47^{\prime \prime} \mathrm{W}\end{array}$ & High grassland & Current study \\
\hline $\begin{array}{l}\text { 2. Simão Pereira, Fazenda } \\
\text { Maglândia, MG } \\
21^{\circ} 58^{\prime} S 43^{\circ} 19^{\prime} \mathrm{W}\end{array}$ & Anthropic field & $\begin{array}{l}\text { GEISE et al., 1996; } \\
\text { GONCCALVES et al., 2005; DE } \\
\text { CONTO and CERQUEIRA, } 2007\end{array}$ \\
\hline $\begin{array}{l}\text { 3. Parque Estadual Serra da } \\
\text { Canastra, MG } \\
20^{\circ} 20^{\prime} S 46^{\circ} 40^{\prime} \mathrm{W}\end{array}$ & $\begin{array}{l}\text { Grassland (open grassland with } \\
\text { predominance of herbaceous } \\
\text { plants and shrubs) }\end{array}$ & $\begin{array}{l}\text { QUEIROLO and GRANZINOLLI, } \\
\text { 2009; VENTURA et al., } 2006\end{array}$ \\
\hline $\begin{array}{l}\text { 4. Juiz de Fora, MG } \\
21^{\circ} 41^{\prime} S 43^{\circ} 27^{\prime} W\end{array}$ & $\begin{array}{l}\text { Semi deciduous forest } \\
\text { surrounded by pasture and } \\
\text { crops }\end{array}$ & $\begin{array}{l}\text { QUEIROLO and GRANZINOLLI, } \\
\text { 2009; VENTURA et al., } 2006\end{array}$ \\
\hline  & Grassland & HERSHKOVITZ, 1990 \\
\hline
\end{tabular}

Source: Created by the authors.

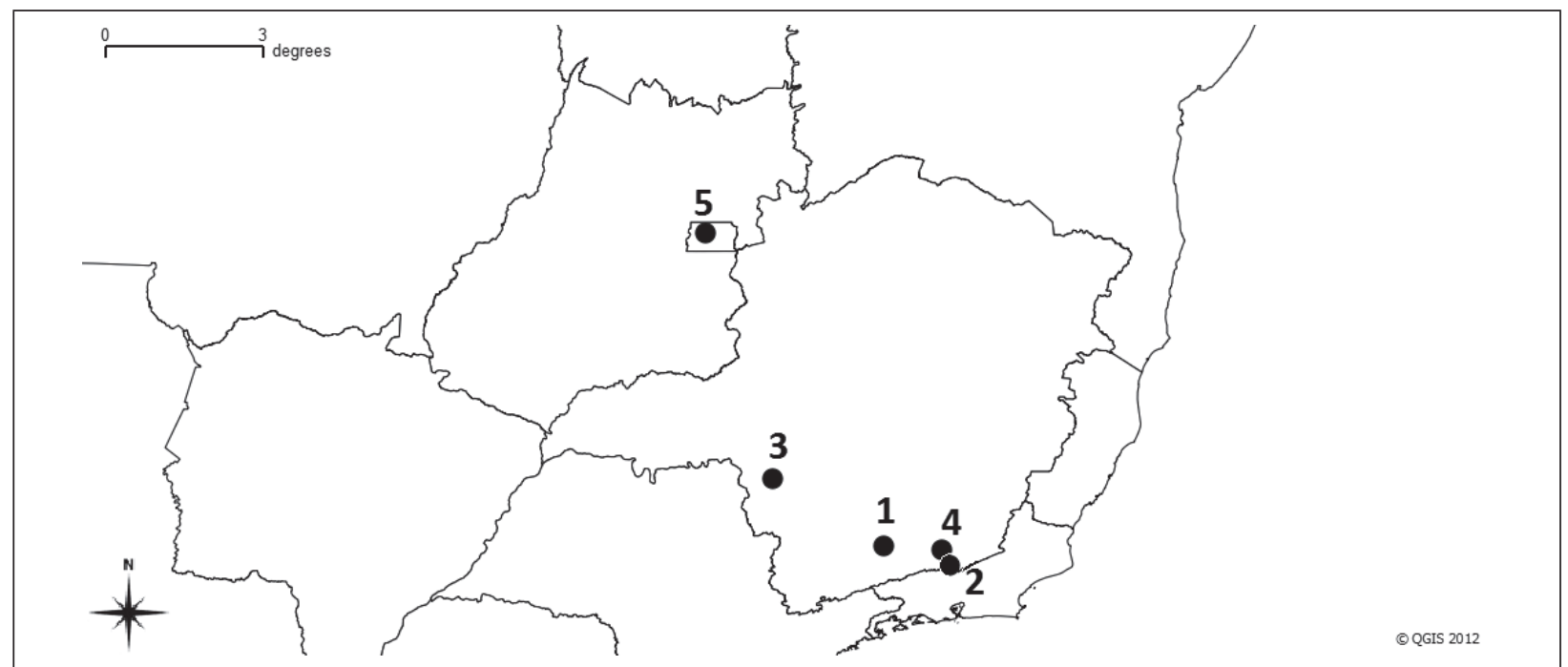

Figure 1. Geographic distribution for A. lindberghi. The numbers refer to the localities on Table 1. Record 5 represents the type locality, Parque Nacional de Brasília, Distrito Federal.

Source: Created by the authors

Bibimys labiosus is found in the states of Minas Gerais, Rio de Janeiro, São Paulo, Paraná, Santa Catarina and Rio Grande do Sul, reaching a total of 17 sites of occurrence (Figure 2). The localities include the domains of Cerrado, Atlantic Forest and the ecotonal zone between both domains. The 
occurrence of this species ranged from 650 to 1,550 m high. Table 2 presents information related to the records of $B$. labiosus.

Table 2. B. labiosus records in Brazil. The number of each report corresponds to the localities representation on Figure 2.

\begin{tabular}{|c|c|c|}
\hline Localities (with coordinates) & Vegetation type & Reference \\
\hline $\begin{array}{l}\text { 1. Minduri, MG } \\
21^{\circ} 45^{\prime} S 44^{\circ} 37^{\prime} \mathrm{W}\end{array}$ & - & Current study \\
\hline $\begin{array}{l}\text { 2. Viçosa, MG. } \\
20^{\circ} 45^{\prime} S 42^{\circ} 53^{\prime} \mathrm{W}\end{array}$ & - & D’ELIA et al., 2005 \\
\hline $\begin{array}{l}\text { 3. Piedade, SP } \\
23^{\circ} 53^{\prime} 9^{\prime \prime} \mathrm{S} 47^{\circ} 29^{\prime} 1 " \mathrm{~W}\end{array}$ & - & MARTINS, 2011 \\
\hline $\begin{array}{l}\text { 4. Carrancas, MG } \\
21^{\circ} 30^{\prime} \mathrm{S} 44^{\circ} 38^{\prime} \mathrm{W}\end{array}$ & - & Current study \\
\hline $\begin{array}{l}\text { 5. Lagoa Santa, MG } \\
19^{\circ} 37^{\prime} \mathrm{S} 43^{\circ} 53^{\prime} \mathrm{W}\end{array}$ & - & $\begin{array}{l}\text { D'ELIA et al., 2005; GONÇALVES } \\
\text { et al., } 2005\end{array}$ \\
\hline $\begin{array}{l}\text { 6. Itapeva, SP } \\
24^{\circ} 10^{\prime} \mathrm{S} 49^{\circ} 5^{\prime} \mathrm{W}\end{array}$ & - & MARTIN et al., 2009 \\
\hline $\begin{array}{l}\text { 7. Parque Estadual da } \\
\text { Cantareira, SP } \\
23^{\circ} 22^{\prime} \mathrm{S} 46^{\circ} 36^{\prime} \mathrm{W}\end{array}$ & - & FUNDAÇÃO FLORESTAL, 2009 \\
\hline $\begin{array}{l}\text { 8. Ouro Branco, MG } \\
20^{\circ} 29^{\prime \prime} \mathrm{S} 43^{\circ} 37^{\prime \prime} \mathrm{W}\end{array}$ & - & BRAGA et al., 2008 \\
\hline $\begin{array}{l}\text { 9. UHE Mauá, PR } \\
24^{\circ} 03^{\prime} 48^{\prime \prime} \mathrm{S} 50^{\circ} 42^{\prime} 05^{\prime \prime} \mathrm{W}\end{array}$ & - & MAUÁ, 2011 \\
\hline $\begin{array}{l}\text { 10. Rio Macacu, RJ } \\
22^{\circ} 27^{\prime} S 42^{\circ} 45^{\prime} \mathrm{W}\end{array}$ & - & MACACU, 2009 \\
\hline $\begin{array}{l}\text { 11. Muitos Capões, Ecological } \\
\text { Station of Aracuri-Esmeralda, RS } \\
28^{\circ} 13^{\prime} S 51^{\circ} 10^{\prime} \mathrm{W}\end{array}$ & - & PERINI, 2010 \\
\hline $\begin{array}{l}\text { 12. São Luiz do Paraitinga, SP. } \\
23^{\circ} 13^{\prime} 19^{\prime \prime} S 45^{\circ} 18^{\prime} 36^{\prime \prime} \mathrm{W}\end{array}$ & - & ZUEC \\
\hline $\begin{array}{l}\text { 13. Ribeirão Grande, SP } \\
24^{\circ} 05^{\prime} 11^{\prime \prime} 48^{\circ} 19^{\prime} 32^{\prime \prime} \mathrm{W}\end{array}$ & Forest fragments & DICOM/USP; MARTINS, 2011 \\
\hline $\begin{array}{l}\text { 14. Cotia, Reserva Florestal } \\
\text { Morro Grande, SP } \\
23^{\circ} 39^{\prime} 4^{\prime \prime} S 46^{\circ} 57^{\prime} 14^{\prime \prime} \mathrm{W}\end{array}$ & $\begin{array}{l}\text { Continuous Atlantic Forest } \\
\text { compounded by stretches of } \\
\text { secondary forests or by better- } \\
\text { structured mature forests. }\end{array}$ & $\begin{array}{l}\text { DICOM/USP; PINOTTI, 2011; } \\
\text { MARTINS, } 2011\end{array}$ \\
\hline $\begin{array}{l}\text { 15. Lavras, Cerradinho UFLA, } \\
\text { MG } \\
21^{\circ} 14^{\prime} \mathrm{S} 45^{\circ} 00^{\prime} \mathrm{W}\end{array}$ & Small fragments of Cerrado s.s. & LECOM/UFLA \\
\hline $\begin{array}{l}\text { 16. Campo Belo do Sul, SC } \\
27^{\circ} 53^{\prime} \mathrm{S} 50^{\circ} 45^{\prime} \mathrm{W}\end{array}$ & Mixed Ombrophilous Forest & SILVEIRA et al., 2012 \\
\hline $\begin{array}{l}\text { 17. Cotiporã, RS } \\
29^{\circ} 0^{\prime} S 51^{\circ} 42^{\prime} W\end{array}$ & Deciduous forest & SILVEIRA et al., 2012 \\
\hline
\end{tabular}

Source: Created by the authors 


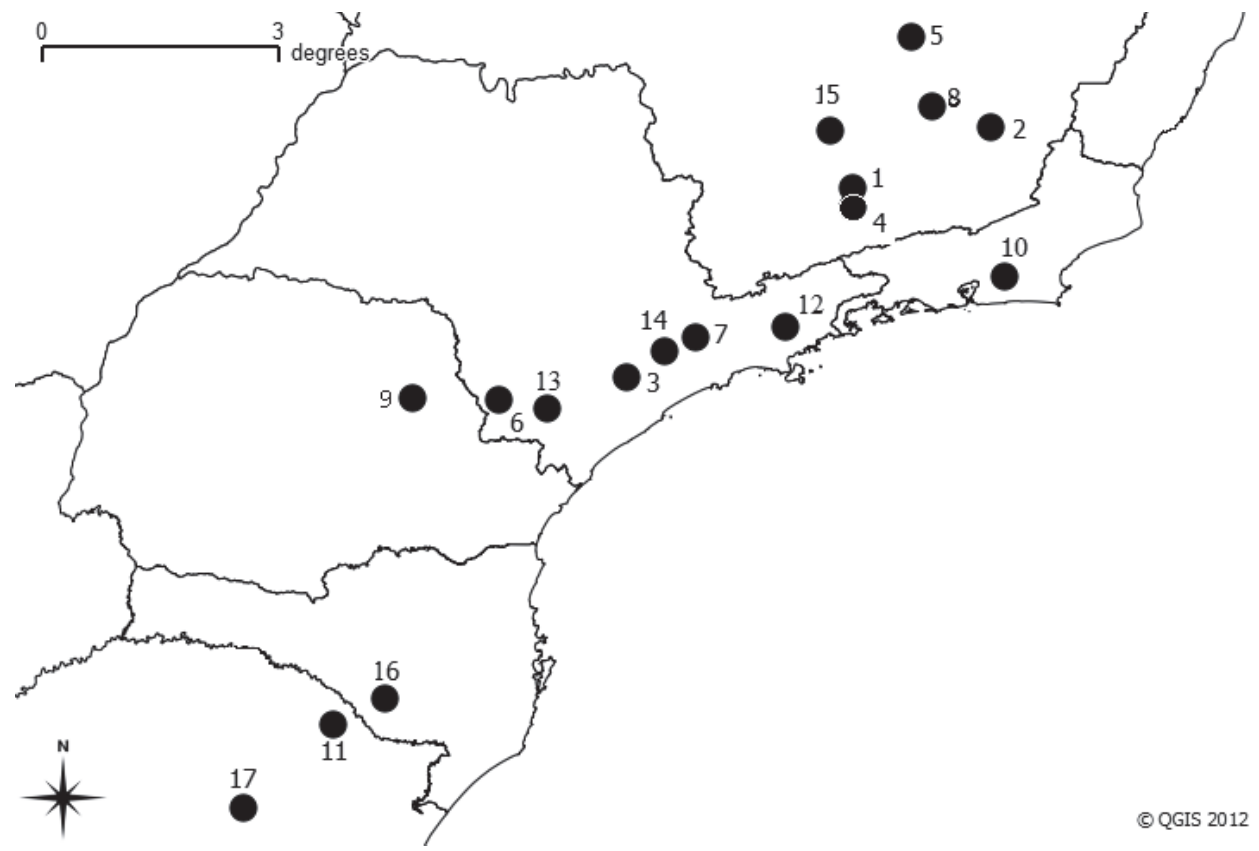

Figure 2. Geographic distribution for B. labiosus in Brazil. Numbers refer to the localities on Table 2.

Source: Created by the authors

The records of $B$. breviceps appeared in the states of Bahia, Minas Gerais, Espírito Santo, Rio de Janeiro and São Paulo, with a total of 39 sites of occurrence (Figure 3). The Atlantic domain is predominant in the areas of occurrence, but the species was also found in areas of Cerrado and ecotonal regions between Atlantic and Cerrado. The points of occurrences ranged from four to $1,570 \mathrm{~m}$ high. Table 3 contains information related to $B$. breviceps records.

Table 3. B. breviceps records in Brazil. The number on each report corresponds to the localities representation on Figure 3.

\begin{tabular}{|c|c|c|}
\hline Locality (with coordinates) & Vegetation type & References \\
\hline $\begin{array}{l}\text { 1. Minduri/Carrancas, Mata Triste, } \\
\text { MG } \\
21^{\circ} 35^{\prime} 35^{\prime \prime} \mathrm{S} 44^{\circ} 35^{\prime} 1^{\prime \prime} \mathrm{W}\end{array}$ & Cloud forest & Current work \\
\hline $\begin{array}{l}\text { 2. Ilhéus, BA } \\
14^{\circ} 47^{\prime} 20^{\prime \prime} \mathrm{S} 39^{\circ} 02^{\prime} 57^{\prime \prime} \mathrm{W}\end{array}$ & - & $\begin{array}{l}\text { MATSON and ABRAVAYA, } 1977 \\
\text { GEISE et al., } 2008\end{array}$ \\
\hline $\begin{array}{l}\text { 3. Buerarema, Ribeirão da } \\
\text { Fortuna, Mata da Lagoa, BA / } \\
\text { Jussari, RPPN Serra do Teimoso, } \\
\text { BA } \\
14^{\circ} 57^{\prime} 34^{\prime \prime S} 39^{\circ} 17^{\prime} 59^{\prime \prime} \mathrm{W}\end{array}$ & Predominantly primary forests & $\begin{array}{l}\text { SILVA et al., 2003; GEISE et al., } \\
2008\end{array}$ \\
\hline $\begin{array}{l}\text { 4. Una, Estação Experimental } \\
\text { CEPLAC, BA / Una, Fazenda } \\
\text { Bolandeira, BA } \\
15^{\circ} 09^{\prime} 00^{\prime \prime} \text { S } 39^{\circ} 31^{\prime} 00^{\prime \prime} \mathrm{W}\end{array}$ & $\begin{array}{l}\text { Edges of primary and secondary } \\
\text { forests }\end{array}$ & $\begin{array}{l}\text { SILVA et al., 2003; PARDINI, } \\
\text { 2004; GEISE et al., } 2008\end{array}$ \\
\hline $\begin{array}{l}\text { 5. Una, Reserva Biológica de Una, } \\
\text { BA } \\
15^{\circ} 16^{\prime} 10^{\prime \prime} S 39^{\circ} 4^{\prime} 9^{\prime \prime} \mathrm{W}\end{array}$ & - & PARDINI, 2004 \\
\hline $\begin{array}{l}\text { 6. Porto Seguro, Estação Ecológica } \\
\text { de Pau Brasil, BA } \\
16^{\circ} 26^{\prime} 58^{\prime \prime} \mathrm{S} 39^{\circ} 3^{\prime} 52^{\prime \prime} \mathrm{W}\end{array}$ & - & GEISE et al., 2008 \\
\hline
\end{tabular}


7. Prado, Fazenda Imbaçuaba, BA -

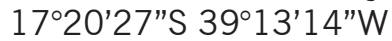

GEISE et al., 2008

8. Conceição do Mato Dentro, -
Boca da Mata, MG
$19^{\circ} 01^{\prime} 43^{\prime \prime} S 43^{\circ} 25^{\prime} 31^{\prime \prime} \mathrm{W}$

9. Lagoa Santa, Lapa do Capão

Seco, MG

19³7'37"S 4353'22"W

MATSON and ABRAVAYA, 1977;

SILVA et al., 2003; GEISE et al., 2008

ABRAVAYA and MATSON, 1975;

MATSON and ABRAVAYA, 1977;

SILVA et al., 2003; GEISE et al., 2008

10. Aracruz, ES

1949'S $40^{\circ} 16^{\prime} \mathrm{W}$ - $\quad$ SILVA et al., 2003; GEISE et al., 2008

11. São Gonçalo do Rio Abaixo e Santa Bárbara, Estação de Proteção e Desenvolvimento Ambiental de Peti, MG $19^{\circ} 53^{\prime} 57^{\prime \prime S} 43^{\circ} 22^{\prime} 07^{\prime \prime} \mathrm{W}$ Secondary forest, transition PAGLIA et al., 2005; GEISE et al., between semi deciduous seasonal 2008 forest and Cerrado s. s. Open areas with small fragments of secondary forest

12. Reserva Florestal de Nova

Lombardia, Mata da Caixa

D’Água, Santa Teresa, ES

1955'S 40³5'W

ABRAVAYA and MATSON, 1975;

MATSON and ABRAVAYA, 1977;

SILVA et al., 2003; GEISE et al., 2008

13. Castelo, Forno Grande, Fazenda Barnabé, ES

$20^{\circ} 30^{\prime} \mathrm{S} 41^{\circ} 04^{\prime} \mathrm{W}$

ABRAVAYA and MATSON, 1975; MATSON and ABRAVAYA, 1977; SILVA et al., 2003; GEISE et al., 2008

14. Viçosa, Mata do Paraíso, MG $20^{\circ} 5^{\prime} \mathrm{S} 42^{\circ} 3^{\prime} \mathrm{W}$

GEISE et al., 2008

15. Cachoeiro do Itapemirim, Open areas with small fragments Castelinho, ES 2050'56"S 4106'46"W of secondary forest ABRAVAYA and MATSON, 1975; SILVA et al., 2003

16. Cariacica, Reserva Biológica de Duas Bocas, ES $20^{\circ} 16^{\prime} \mathrm{S} 40^{\circ} 28^{\prime} \mathrm{W}$

Dense ombrophilous forest with mosaic of primary and secondary

FAGUNDES and COSTA, 2008 vegetation with 50 years of regeneration

17. Juiz de Fora, MG - GEISE et al., 2008 $21^{\circ} 41^{\prime} \mathrm{S} 43^{\circ} 27^{\prime} \mathrm{W}$

18. Teresópolis, Fazenda Colônia Approximately 70 years old Alpina e Fazenda Boa Fé, RJ secondary forest $22^{\circ} 19^{\prime} \mathrm{S} 42^{\circ} 59^{\prime} \mathrm{W}$ MATSON and ABRAVAYA, 1977; SILVA et al., 2003; GEISE et al., 2008

19. Mauá, Fazenda Marimbondo, Mixed ombrophilous forest $\quad$ GEISE et al., 2008 $\mathrm{SP}$ 2221'38"S 4434'9"W

\begin{tabular}{|c|c|c|}
\hline $\begin{array}{l}\text { 20. Valença, Santuário Serra da } \\
\text { Concórdia, RJ } \\
22^{\circ} 22^{\prime} 18 S 43^{\circ} 47^{\prime} 23^{\prime \prime} W\end{array}$ & Semi deciduous forest & $\begin{array}{l}\text { GEISE et al., 2008; MODESTO et } \\
\text { al., } 2008\end{array}$ \\
\hline
\end{tabular}

21. Santa Isabel, RPPN Rio dos PILÕES, 2007 Pilões, SP 317'48"S 46¹7'26"W 


\begin{tabular}{|c|c|c|}
\hline $\begin{array}{l}\text { 23. Santo André, SP } \\
23^{\circ} 39^{\prime} 50^{\prime \prime} \mathrm{S} 46^{\circ} 32^{\prime} 18^{\prime \prime} \mathrm{W}\end{array}$ & $\begin{array}{l}\text { Tropical forest with recent history } \\
\text { of deforestation }\end{array}$ & $\begin{array}{l}\text { SILVA et al., 2003, GEISE et al., } \\
2008\end{array}$ \\
\hline $\begin{array}{l}\text { 24. Cotia, Morro Grande Forest } \\
\text { Reserve, SP } \\
23^{\circ} 39^{\prime} \mathrm{S} 47^{\circ} 01^{\prime} \mathrm{W}\end{array}$ & - & $\begin{array}{l}\text { PARDINI and UMETSU, 2006; } \\
\text { GEISE et al., } 2008\end{array}$ \\
\hline $\begin{array}{l}\text { 25. São Miguel Arcanjo e Pilar do } \\
\text { Sul, Fazenda João XXIII, SP } \\
23^{\circ} 53^{\prime} S 48^{\circ} 0^{\prime} W\end{array}$ & $\begin{array}{l}\text { Altered dense ombrophilous forest, } \\
\text { fragments of secondary forest } \\
\text { circled by eucalypts }\end{array}$ & ANTUNES and ESTON, 2010 \\
\hline $\begin{array}{l}\text { 26. Tapiraí, Capão Bonito, SP } \\
23^{\circ} 57^{\prime} \mathrm{S} 47^{\circ} 30^{\prime} \mathrm{W}\end{array}$ & Altered dense ombrophilous forest & ANTUNES and ESTON, 2010 \\
\hline $\begin{array}{l}\text { 27. Parque Estadual da Cantareira } \\
\text { e Sete Barras, SP } \\
24^{\circ} 22^{\prime} S 47^{\circ} 56^{\prime} \mathrm{W}\end{array}$ & Altered dense ombrophilous forest & NIERI BASTOS et al., 2004 \\
\hline $\begin{array}{l}\text { 28. Iporanga, Parque Estadual } \\
\text { Turístico do Alto Ribeira (PETAR), } \\
\text { SP } \\
24^{\circ} 35^{\prime} 08^{\prime \prime S} 48^{\circ} 35^{\prime} 35^{\prime \prime} \mathrm{W}\end{array}$ & $\begin{array}{l}\text { Mosaic of primary and secondary } \\
\text { formations }\end{array}$ & $\begin{array}{l}\text { SILVA et al., 2003; GEISE et al., } \\
2008\end{array}$ \\
\hline
\end{tabular}

\begin{tabular}{|c|c|}
\hline $\begin{array}{l}\text { 29. Camacan, Serra Bonita, BA } \\
15^{\circ} 25^{\prime} \mathrm{S} 39^{\circ} 29^{\prime} \mathrm{W}\end{array}$ & VENTURA et al., 2012 \\
\hline $\begin{array}{l}\text { 30. Jequitinhonha, Mata Escura, } \\
\text { MG } \\
16^{\circ} 26^{\prime} \text { S } 41^{\circ} 00^{\prime} \mathrm{W}\end{array}$ & VENTURA et al., 2012 \\
\hline
\end{tabular}

31. Trancoso, Fazenda Nova $\quad-\quad$ VENTURA et al., 2012
Alegria, BA
1631' S 3907' W

32. Pinheiros, REBIO Córrego do Veado, ES

$18^{\circ} 21^{\prime}$ S $40^{\circ} 09^{\prime} \mathrm{W}$

VENTURA et al., 2012

\begin{tabular}{lcc}
\hline 33. Linhares, ES & - & VENTURA et al., 2012 \\
19॰39' S $40^{\circ} 07^{\prime} \mathrm{W}$ & & \\
\hline 34. Catas Altas, Estr. Mariana- & - & VENTURA et al., 2012 \\
Catas Altas, MG & & \\
$20^{\circ} 11^{\prime} \mathrm{S} 43^{\circ} 29^{\prime} \mathrm{W}$ &
\end{tabular}

35. Ouro Branco, Serra do Ouro - _ VENTURA et al., 2012

Branco, MG

20³0' S 4337' W

36. Alto Caparaó, PARNA

Caparaó-Linha 2 e Córrego do

Calçado, MG

$20^{\circ} 25^{\prime}$ S $41^{\circ} 50^{\prime}$ W e $20^{\circ} 28^{\prime} \mathrm{S}$

$41^{\circ} 44 \mathrm{~W}$

37. Biritiba-Mirim, SP - _ VENTURA et al., 2012

235' $46^{\circ} 03^{\prime} \mathrm{W}$

38. Natividade da Serra, PE Serra - VENTURA et al., 2012

do Mar, SP

2319' S 4505' W

39. São Bernardo do Campo, SP

2369' S 4656' W

Source: Created by the authors 




Figure 3. Geographic distribution for $B$. breviceps in Brazil. The numbers refer to the localities on Table 3. Point 8 represents the type-locality Lagoa Santa, MG.

Source: Created by the authors

Pseudoryzomys simplex appears in the states of Pernambuco, Bahia, Minas Gerais, São Paulo, Tocantins, Goiás and Distrito Federal meeting a total of 14 sites of occurrence (Figure 5). The predominant domain in which $P$. simplex appeared was Cerrado. Although, there are records for Atlantic Forest and ecotonal regions between Cerrado and Atlantic Forest. The occurrence ranged from 140 to $1,550 \mathrm{~m}$ high. Table 4 contains information related to $P$. simplex records.

Recently, Patton et al. (2015) increase the number of records out of Brazil. The records include records at northeastern Argentina, western Paraguay, eastern Bolivia and the Pampas del Heath in extreme southeastern Peru. To Brazil, other records include the states of Amapá and Amazonas (see map of distribution to $P$. simplex in Patton et al. 2015). 
Table 4. P. simplex records in Brazil. The number on each report corresponds to the localities representation on Figure 4.

\begin{tabular}{lll}
\hline Localities (with coordinates) & Vegetation type & Reference \\
\hline 1. Minduri and Carrancas, & - & Current study \\
Mata Triste, MG & & \\
$21^{\circ} 35^{\prime} 35^{\prime \prime} S 44^{\circ} 35^{\prime} 1$ 'W & & \\
\hline
\end{tabular}

2. São Lourenço da Mata,

RODA, 2006

Estação Ecológica Tapacurá, PE

$8^{\circ} 02^{\prime} \mathrm{S} 35^{\circ} 13^{\prime} \mathrm{W}$

3. Santa Rita do Passa Quatro,

ARIE Cerrado Pé-de-Gigante, SP

$21^{\circ} 40^{\prime} \mathrm{S} 47^{\circ} 43^{\prime} \mathrm{W}$

4. Parque Nacional da Chapada dos Veadeiros, GO $13^{\circ} 31^{\prime} \mathrm{S} 47^{\circ} 34^{\prime} \mathrm{W}$
Humid grassland, "Vereda",

Cerrado s. s., grassland, Rupestrian Cerrado and gallery forest.

5. Prata, Salto and Parque

Estadual Ponte, MG

-

JORGE, 1999

19¹2'46"S 4848'43"W

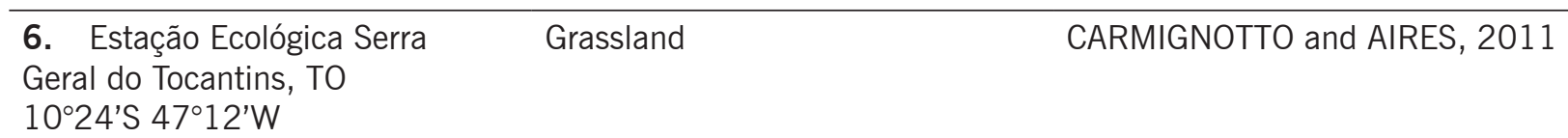

7. Palmeiras, Chapada

Diamantina, BA

Open vegetation, Rupestrian

PEREIRA and GEISE, 2009

$12^{\circ} 25^{\prime} \mathrm{S} 41^{\circ} 25^{\prime} \mathrm{W}$

\begin{tabular}{ll}
\hline 8. Mucugê, Chapada & Open area, Cerrado \\
Diamantina, BA & \\
$12^{\circ} 59^{\prime} S 41^{\circ} 23^{\prime} \mathrm{W}$ &
\end{tabular}

9. Ilha do Bananal, Parque Open area BEZERA et al., 2009

Nacional do Araguaia, TO

10²7'S 50²9'W

10. Parque Nacional das Emas, Open area RODRIGUES et al., 2002

18¹5'50"S 5253'33"W

11. Panga, Reserva Ecológica

BRUNA et al., 2010

de Panga, $M G$

$19^{\circ} 10^{\prime} \mathrm{S} 48^{\circ} 23^{\prime} \mathrm{W}$

12. Parque Nacional das Emas, GO

CÁCERES et al., 2008

186'23"S 5255'40"W

\begin{tabular}{lll}
\hline 13. Brasília, Reserva Ecológica & Gallery forest & FONSECA and REDFORD, 1984 \\
do IBGE, DF & & \\
$15^{\circ} 56^{\prime} 41^{\prime \prime}$ S $47^{\circ} 53^{\prime} 07^{\prime \prime} \mathrm{W}$ & & VOSS and MYERS, 1991 \\
\hline 14. Lagoa Santa, Lapa do Capão & - & \\
Seco, MG & & \\
$19^{\circ} 37^{\prime} 37^{\prime \prime}$ S $43^{\circ} 53^{\prime} 22^{\prime \prime} \mathrm{W}$ & & \\
\hline
\end{tabular}

Source: Created by the authors 


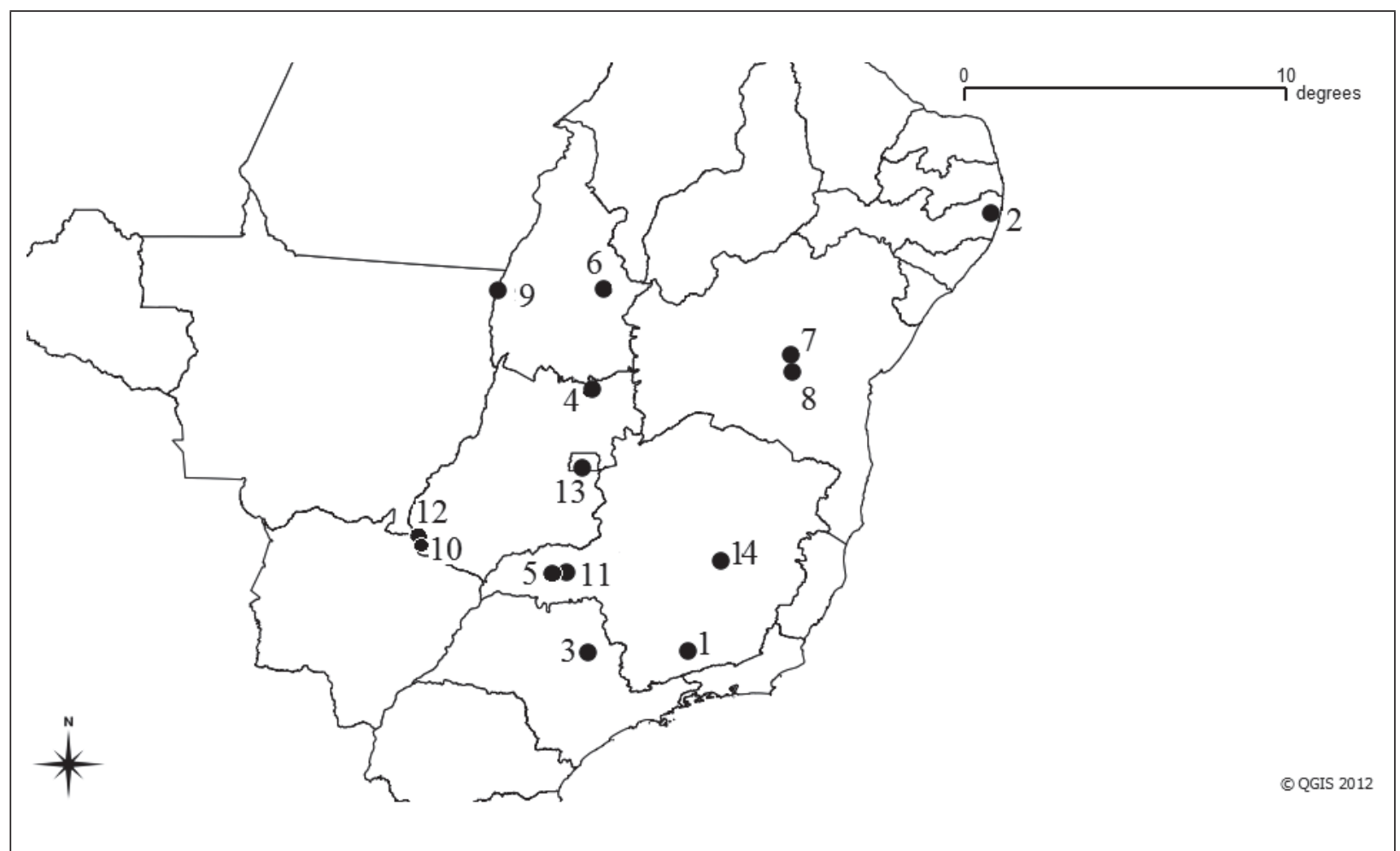

Figure 4. Geographic distribution for $P$. simplex in Brazil. The numbers refer to the localities on Table 4. Point 14 represents the type-locality Lagoa Santa, MG.

Source: Created by the authors

\section{Discussion}

Information related to Akodon lindberghi on the literature is scarce; hence, the species is classified as vulnerable on Cerrado by IUCN (MARINHO-FILHO et al., 2008). Our record (Minduri/Carrancas towns) adds information about this species occurrence. Figure 1 evidences the considerable gap in the points and this may be caused mainly by problems with the correct identification of animals from the genus Akodon in the field, as well as lack of material collection and appropriate proceedings in identifying specimens, non-karyotyping for example. Indeed, Vivo (2007) pointed out that those proceedings are doubtful because they do not have control material to make the identification, which prevents the comprehension of part of its biology.

Furthermore, Gonçalves et al. (2005) mention the need for a taxonomic revision of A. lindberghi and Akodon mystax. Both species belong to the group of small Akodon and what differentiates one from the other is qualitatively the presence or absence of masseteric tubercle. If a species is a synonym of the other, the number of locality can triple (see occurrence to both species in Gonçalves et al., 2005).

The type locality of $A$. lindberghi is the Parque Nacional de Brasília inserted in the biome Cerrado, but the species also were found in areas of Atlantic Forest and the ecotone Atlantic Forest/Cerrado, corroborating Queirolo and Granzinolli (2009) and Paglia et al. (2012).

Although $B$. labiosus is not classified in any threaten degree, its population are fragmented and tend to decrease (PARDIÑAS et al., 2008a), chiefly due to the current situation of biomes preservation in which it occurs, Cerrado (PARDIÑAS et al., 2008a) and Atlantic Forest (PAGLIA et al., 2012). Rovida (2010) asserted that this species is endemic of Cerrado; Paglia et al. (2012) mentioned the 
occurrence of this species exclusively to Atlantic Forest. However, records from CMUFLA show its occurrence in an ecotonal region between Cerrado and Atlantic Forest. Therefore, more studies related to biology and zoogeographies of those species are necessary.

In addition, the specimen in LECOM/UFLA was captured within the urban area of Lavras, near a forest called "Cerradinho" that is highly modified for various research activities conducted by UFLA. Thus, and as exposed by Lessa et al. (1999), it is believed that $B$. labiosus requires low demands from the environment.

Blarinomys breviceps is not classified in any threaten degree. However, its populations are fragmented and tend to decrease (PARDIÑAS et al., 2008b). This species presents wide distribution (PAGLIA et al., 2012), including the Atlantic domain (predominant in the occurrence areas), Cerrado (SILVA et al., 2003) and ecotonal regions between these two domains. This species is associated to both montane regions and forests of low elevation (SILVA et al., 2003; PARDINI, 2004). All of the specimens from CMUFLA, for example, were captured in pitfalls, at approximately $1,550 \mathrm{~m}$ in cloudy forests. The species is considered rare, but the scarcity of records may be explained by the potential low population density (PEREIRA et al., 2008) and also by sampling aspects. Indeed, Umetsu et al. (2006) pointed out that small pitfalls ( $35 \mathrm{~L}$ capacity) may be efficient on capturing more individuals of Blarinomys, but that is a recently used technique to capture small mammals.

Pseudoryzomys simplex suggests a lack of knowledge about its biology (TALAMONI et al., 2000; BONVICINO et al., 2002; PARDIÑAS et al., 2004) despite the fact that studies involving important information about this species are being developed. In effect, reports about this species are rare due to problems on identification in field, lack of samples and methodological issues. However, new records have extended the occurrence of the species up to 2,000 km from the nearest previous records (PARDIÑAS et al., 2004). Reports of occurrence of $P$. simplex have been increasing due to the great amount of carcass found in owl regurgitation (mainly Tyto alba) (TALAMONI et al., 2000; PARDIÑAS et al., 2004; TETA et al., 2009; TETA and PARDIÑAS, 2010). Most of those records are concentrated near the region of Rio Paraná, region considered the east limit of this species (PARDIÑAS et al., 2004). Bonvicino et al. (2002) commented that $P$. simplex is a rare species of Cerrado, being restricted to humid environments, wet grasslands vegetation and low altitudes, facts corroborated by Voss and Myers (1991) and Pardiñas et al. (2004). However, the specimen of $P$. simplex from CMUFLA was captured in cloud forest at $1,550 \mathrm{~m}$ high and $50 \mathrm{~m}$ from a stream, what excludes the possibility of this species being restricted to low altitude habitat.

\section{Acknowledgement}

We thank Mr. Edgar Cortez, who kindly hosted us and allowed the studies in his property, and Alexandre R. Percequillo, for the help on identifying some specimens. We also thank the curators' collections: Ivan Sazima (ZUEC), Renata Pardini (DICOM/USP) and Marcelo Passamani (LEM/UFLA). CAPES, FAPEMIG and CNPq for supporting this study.

\section{Resumo}

O grupo mais representativo entre os mamíferos são os roedores, por apresentarem elevada proporção em relação ao total de espécies. Apesar da representatividade, esse grupo é considerado um "caos taxonômico" e algumas espécies são pouco conhecidas, entre elas Blarinomys breviceps, Bibimys labiosus, Akodon lindberghi e Pseudoryzomys simplex, pela baixa ocorrência em inventá- 
rios faunísticos de pequenos mamíferos terrestres e/ou reduzida abundância. O objetivo é descrever os locais de ocorrência dessas espécies e, posteriormente, analisar essas localidades apresentando comentários descritivos sobre seus aspectos biológicos. Para isso, além de coletas de espécimes em campo, algumas coleções científicas foram visitadas, pesquisas em bibliografia especializada foram realizadas com o intuito de obter informações sobre as localidades e aspectos biológicos. Akodon lindberghi foi encontrada em cinco locais, Bibimys labiosus foi encontrada em 15, Blarinomys breviceps em 39 e Pseudoryzomys simplex em 13. Cada espécie apresenta características específicas e elas estão incluídas em dois domínios ameaçados, Mata Atlântica e Cerrado. As ocorrências são disjuntas e relacionadas a problemas taxonômicos e metodológicos.

Palavras-chave: Novos relatórios. Rodentia. Sigmodontinae. Área de ocorrência.

\section{References}

ABRAVAYA, J. P.; MATSON, J. O. Notes on a Brazilian mouse Blarinomys breviceps (Winge). Contributions in Science of the Natural History Museum of Los Angeles County, v. 270, p. 1-8, 1975.

ANTUNES A. Z.; ESTON M. R. Registro de Blarinomys breviceps (Winge, 1888) (Cricetidae, Rodentia) no Parque Estadual Carlos Botelho - SP. Revista Instituto Florestal, v. 22, n. 1, p. 171-175, 2010.

BELENTANI, S. C. S. Ecologia alimentar do Lobo-guará, Chrysocyon brachyurus (Mammalia: Canidae), no Parque Florestal Salto e Ponte, município de Prata, MG. 2001. 71 p. (Dissertação). Universidade de São Paulo, São Paulo. 2001.

BEZERRA, A. M. R.; CARMIGNOTTO, A. P.; RODRIGUES, F. H. G. Small non-volant mammals of an ecotone region between the Cerrado hotspot and the Amazonian rainforest, with comments on their taxonomy and distribution. Zoological Studies, v. 48, p. 861-874, 2009.

BONVICINO, C. R.; LINDBERGH, S. M.; MAROJA, L. S. Small non-flying mammals from conserved and altered areas of Atlantic forest and Cerrado: comments on their potential use for monitoring environment. Brazilian Journal of Biology, v. 62, p. 765-774, 2002.

BONVICINO, C. R.; OLIVEIRA, J. A.; D'ANDREA, P. S. Guia dos Roedores do Brasil, com chaves para gêneros baseadas em caracteres externos. Rio de Janeiro: Centro Pan-Americano de Febre Aftosa OPAS/OMS. 120 p. 2008.

BRAGA, C. A. C.; LEVY, M. O. P.; GRAMIGNA, T. H. A.; SOUZA, H. C. Análise da dieta de B. labiosus. In: Anais da IV Congresso Brasileiro de Mastozoologia, 2008, São Lourenço, MG. Disponível em: https://plus.google.com/events/cn895dophvksll7u6qpt6g9dobk. Acesso em: 10 mai. 2014.

BRUnA, E. M.; GUIMARÃES, J. F.; LOPES, C. T.; DUARTE, P.; GOMES, A. C. L.; BELENTANI, S. C. S.; PACHECO, R.; FACURE, K. G.; LEMOS, F. G.; VASCONCELOS, H. L. Mammalia, Estação Ecológica do Panga, a Cerrado protected area in Minas Gerais state, Brazil. Check List, v. 6, n. 4, p. 668-675, 2010.

CÁCERES, N. C.; CARMignOtTO, A. P.; FISCHER, E.; SANTOS, C. F. Mammals from Mato Grosso do Sul, Brazil. Check List, v. 4, n. 3, p. 321-335, 2008. 
CARMIGNOTTO, A. P.; AIRES, C. C. Mamíferos não voadores (Mammalia) da Estação Ecológica Serra Geral do Tocantins. Biota Neotropica, v. 11, n. 1, p. 313-328, 2011.

DALANESI, P. A.; OLIVEIRA-FILHO, A. T.; FONTES, M. A. L. Flora e estrutura do componente arbóreo da floresta do Parque Ecológico Quedas do Rio Bonito, Lavras, MG, e correlações entre a distribuição das espécies e variáveis ambientais. Acta Botanica Brasilica, v. 18, n. 4, p. 737-757, 2004.

DE CONTO, V.; CERQUEIRA, R. Reproduction, development and growth of Akodon lindberghi (Hershkovitz, 1990) (Rodentia, Muridae, Sigmodontinae) raised in captivity. Brazilian Journal of Biology, v. 67, n. 4, p. $707-713,2007$.

D'ELÍA, G.; PARDIÑAS, U. F. J.; MYERS, P. An introduction to the genus Bibimys (Rodentia: Sigmodontinae) phylogenetic position and alpha taxonomy. In: LACEY, E.; MYERS, P. (Eds.). Mammalian diversification in the Neotropics: from chromosomes to phylogeography (a celebration of the career James $L$. Patton). University of California Publication on Zoology, v. 133, Berkeley, California, p. 211-246, 2005.

DE VIVO, M. Problemas da mastozoologia brasileira. Boletim da Sociedade Brasileira de Mastozoologia, v. 48, p. 1 - 4, 2007.

DRUMMOND, G. M.; MARTINS, C. S.; MACHADO, A. B. M.; SEBAIO, F. A.; ANTONINI, Y. Biodiversidade em Minas Gerais: um atlas para a sua conservação. Belo Horizonte: Fundação Biodiversitas. 2005.

FAGUNDES, V. E.; COSTA, L. Um cariótipo novo para Blarinomys breviceps (Winge, 1887): um caso de erro de identificação ou uma nova espécie no gênero? Congresso Brasileiro de Genética, Brasil, 2008.

FONSECA, G. A. B.; REDFORD, K. H. The mammals of IBGE'S ecological reserve, Brasília, and analysis of the role of gallery forest in increasing diversity. Revista Brasileira de Biologia, v. 44, n. 4, p. 517-523, 1984.

FORD, C. E.; HAMERTON, J. L. A colchicine hypotonic citrate squash sequence for mammalian chromosomes. Stain Tech. v. 31, p. 247-251. 1956.

FUNDAÇÃO FLORESTAL. Plano de Manejo do Parque Estadual da Cantareira. São Paulo (SP): Fundação Florestal, 2009. Disponível em: http://www.fflorestal.sp.gov.br/media/uploads/planosmanejo/ PECantareira/Anexos/Anexo\%207.\%20Esp\%C3\%A9cies\%20de\%20Roedores\%20Registradas\%20 no\%20PEC.pdf. Acesso em: 03 mai. 2016.

GEISE, L.; BERGALLO, H. G.; ESBERARD, C. E. L.; ROCHA, C. F. D.; SLUYS, M. V. The karyotype of (Mammalia: Rodentia: Cricetidae) with comments on its morphology and some ecological notes. Zootaxa, v. 907, p. 47-60, 2008.

GEISE, L.; CERQUEIRA, R.; SEUÁNEZ, H. N. A. Karyological characterization of a new population of Akodon lindberghi (Rodentia, Sigmodontinae) in Minas Gerais State (Brazil). Caryologia, v. 49, p. 57-63, 1996.

GONÇALVES, P. R.; MYERS, P.; VILELA, J. F.; OLIVEIRA, J. A. Systematics of species of the genus Akodon (Rodentia: Sigmodontinae). Miscellaneous Publications, p. 1-24, 2007. 
GONÇALVES, P. R.; OLIVEIRA, J. A.; OLIVEIRA, M. C.; PESSÔA, L. M. Morphological and cytogenetic analyses of Bibimys labiosus (Winge, 1887) (Rodentia, Sigmodontinae): implications for its affinities with the Scapteromyine group. In: LACEY, E. A.; MYERS, P. Mammalian diversification in the Neotropics: from chromosomes to phylogeography (Special volume in honor of James L. Patton). University of California Publication on Zoology, Berkeley, California, 2005. p. 175-209.

HERSHKOVITZ, P. Mice of the Akodon boliviensis size class (Sigmodontinae, Cricetidae) with the description of two new species from Brazil. Fieldiana Zoology, v. 57, p. 1-35, 1990.

LESSA, G.; GONÇALVES, P. R.; MORAIS-JUNIOR, M. M.; COSTA, F. M.; PEREIRA, R. F.; PAGLIA, A. $P$. Caracterização e monitoramento da fauna de pequenos mamíferos terrestres de um fragmento de mata secundária em Viçosa, Minas Gerais. Bios, v. 7, n. 7, p. 41-49, 1999.

LYRA-JORGE, Maria Carolina. Avaliação do Potencial Faunístico da A.R.I.E. Cerrado Pé-de-Gigante (Parque Estadual de Vassununga, Santa Rita do Passa-Quatro - SP), com Base na Análise de Habitats. 1999. Dissertação (Mestrado em Ecologia: Ecossistemas Terrestres e Aquáticos) - Instituto de Biociências, Universidade de São Paulo, São Paulo, 1999. Disponível em: <http://www.teses.usp.br/ teses/disponiveis/41/41134/tde-24042006-164049/>. Acesso em: 03 mai. 2016.

MACACU. Lista de espécies da mastofauna da bacia do Macacu. 2009. Cachoeiras de Macacu (RJ). Disponível em: http://pib.socioambiental.org/anexos/6679_20091117_104602.pdf. Acesso em: 03 mai. 2016.

MARINHO-FILHO, J.; GEISE, L.; QUEIROLO, D. Akodon lindberghi. 2008. IUCN Red List of Threatened Species. Disponível em: www.iucnredlist.org. Acesso em: 03 mai. 2016.

MARTIN, P. S.; GHELER-COSTA, C.; VERDADE, L. M. Microestrutura de pêlos de pequenos mamíferos não voadores chave para identificação de espécies de agrossistemas do estado de São Paulo, Brasil. Biota Neotropica, v. 9, n. 1, 2009.

MARTINS, T. K. Determinantes ecológicos do risco de extinção: abundância local, amplitude de nicho, capacidade de dispersão e a resposta das espécies de pequenos mamíferos à fragmentação florestal no Planalto Atlântico Paulista. 2011. Dissertação (Mestrado em Zoologia) - Instituto de Biociências, Universidade of São Paulo, São Paulo, 2011. Disponível em: <http://www.teses.usp.br/ teses/disponiveis/41/41133/tde-19042012-101419/>. Acesso em: 03 mai. 2016.

MATSON, J. O.; ABRAVAYA, J. P. Blarinomys breviceps. Mammalian Species, v. 74, p. 1-3, 1977.

MAUÁ. Relatório de atividades mensais da UHE Mauá. 2011. Ortigueira (PR). Disponível em: http:// www.consorciocruzeirodosul.com.br/upload/tiny_mce/arquivos/meio_ambiente/Relatorio_de_Resgate_de_Fauna_-_Fevereiro_11.pdf. Acesso em: 03 mai. 2016.

MODESTO, T. C.; PESSÔA, F. S.; JORDÃO-NOGUEIRA, T.; ENRICI, M. C.; COSTA, L. M.; ATTIAS, N.; ALMEIDA, J.; RAÍCES, D. S. L.; ALBUQUERQUE, H. G.; PEREIRA, B. C.; ESBÉRARD, C. E. L.; BERGALLO, H. G. Mammals, Serra da Concórdia, state of Rio de Janeiro, Brazil. Check List, v. 4, n. 3, p. 341-348, 2008.

NIERI-BASTOS, F. A.; BARROS-BATTESTI, D. M.; LINARDI, P. M.; AMAKU, M.; MARCILI, A.; FAVORITO, S. E.; PINTO-DA-ROCHA, R. Ectoparasites of wild rodents from Parque Estadual da Cantareira 
(Pedra Grande Nuclei), São Paulo, Brazil. Revista Brasileira de Parasitologia Veterinaria, v. 13, n. 1, p. 29-35, 2004.

OLIVEIRA-FILHO, A. T.; CARVALHO, D. A.; FONTES, M. A. L.; VAN DEN BERG, E.; CURI, N.; CARVALHO, W. A. C. Variações estruturais do compartimento arbóreo de uma floresta semidecídua alto-montana na chapada das Perdizes, Carrancas, MG. Revista Brasileira de Botânica, v. 27, p. 291-309, 2004.

PAGLIA, A. P.; FONSECA, G. A. B.; RYLANDS, A. B.; HERRMANN, G.; AGUIAR, L. M. S.; CHIARELLO, A. G.; LEITE, Y. L. R.; COSTA, L. P.; SICILIANO, S.; KIERULFF, M. C. M.; MENDES, S. L.; TAVARES, V. C.; MITTERMEIER, R. A.; PATTON, J. L. Lista Anotada dos Mamíferos do Brasil. 2ed. Occasional Paper In Conservation Biology. Arlington,VA, USA. 2012.

PAGLIA, A. P.; PERINI, F. A.; LOPES, M. O. G.; PALMUTI, C. F. S. Novo registro de Blarinomys breviceps (Winge, 1888) (Rodentia, Sigmodontinae) no estado de Minas Gerais, Brasil. Lundiana, v. 6, n. 2 , p. $155-157,2005$.

PARDIÑAS, U. F. J.; CIRIGNOLI, S.; GALLIARI, C. A. Distribution of Pseudoryzomys simplex (Rodentia: Cricetidae) in Argentina. Mastozoologia Neotropical, v. 11, p. 105-108, 2004.

PARDIÑAS, U.; PATTERSON, B.; D'ELIA, G.; TETA, P. Bibimys labiosus. 2008a. IUCN Red List of Threatened Species. Disponível em: www.iucnredlist.org. Acesso em: 03 mai. 2016.

PARDINAS, U.; PATTERSON, B.; D'ELIA, G.; TETA, P. Blarinomys breviceps. 2008b. IUCN Red List of Threatened Species. Disponível em: www.iucnredlist.org. Acesso em: 03 mai. 2016.

PARDINI, R. Effects of forest fragmentation on small mammals in an Atlantic Forest landscape. Biodiversity and Conservation, v. 13, p. 2567-2586, 2004.

PARDINI, R.; UMETSU, F. Pequenos mamíferos não-voadores da Reserva Florestal do Morro Grande - distribuição das espécies e da diversidade em uma área de Mata Atlântica. Biota Neotropica, v. 6, n. 2, p. 1-22, 2006.

PATTERSON, B. D. Patterns and trends in the discovery of new Neotropical mammals. Diversity and Distributions, v. 6, n. 3, p. 145-151, 2000.

PATTON, J. L.; PARDiÑAS, U. F. J.; D’ELÍA, G. (Ed.). Mammals of South America, Volume 2: Rodents. University of Chicago Press, 2015, 1363 p.

PEREIRA, J. A. A.; OLIVEIRA-FILHO, A. T.; LEMOS-FILHO, J. P. Environmental heterogeneity and disturbance by humans control much of the tree species diversity of Atlantic montane forest fragments in SE Brazil. Biological Conservation, 2006, 187-210.

PEREIRA, L. G.; GEISE, L.; CUNHA, A. A.; CERQUEIRA, R. Abrawayaomys ruschii Cunha and Cruz, 1979 (Rodentia, Cricetidae) no Estado do Rio de Janeiro, Brasil. Papéis Avulsos em Zoologia, v. 48, n. 5, p. 33-40, 2008.

PEREIRA, L. G.; GEISE, L. N. Non-flying mammals of Chapada Diamantina (Bahia, Brazil). Biota Neotropica, v. 9, n. 3, p. 185-196, 2009. 
PERINI, A. A. A importância da Araucaria angustifolia na dieta de pequenos roedores silvestres em área de Floresta com Araucária no sul do Brasil. 2010. 43 p. Dissertação. Universidade do Vale dos Sinos. 2010.

PILÕES. Plano de Manejo da RPPN Rio dos Pilões. 2007. Disponível em: http://www.ibirapitanga. com/images/RPPN_RIO_DOS_PILOES_Mamiferos.pdf. Acesso em: 03 mai. 2016.

PINOTTI, B. T. Pequenos mamíferos terrestres e a regeneração da Mata Atlântica: influência da estrutura de habitat e da disponibilidade de alimento na recuperação da fauna. 2011. 124 p. Dissertação. Universidade de São Paulo, 2011.

QUEIROLO, D.; GRANZINOLLI, M. A. M. Ecology and natural history of Akodon lindberghi in southeastern Brazil. Iheringia, v. 99, n. 2, p. 189-193, 2009.

RODA. S. A. Dieta de Tyto alba na Estação Ecológica do Tapacurá, Pernambuco, Brasil. Revista Brasileira de Ornitologia, v. 14, n. 4, p. 449-452, 2006.

RODRIGUES, V. E. G.; CARVALHO, D. A. Levantamento etnobotânico de plantas medicinais no domínio do Cerrado na região do Alto Rio Grande. Ciência e Agrotecnologia, v. 25, n. 1, p. 102-123, 2001.

RODRIGUES, F. H. G.; SILVEIRA, L.; JÁCOMO, A. T. A.; BEZERRA, A. P.; COELHO, A. M. R.; SANTOS, D. C.; PAGNOZZI, H. G.; HASS, A. Composição e caracterização da fauna de mamíferos do Parque Nacional das Emas, Goiás, Brasil. Revista Brasileira de Zoologia, v. 19, n. 2, p. 589-600, 2002.

ROVIDA, J. C. Predição de tetrápodes ameaçados no Cerrado baseada na relação espécies-área. 2011. 60 p. Dissertação. Universidade de Goiás. 2011.

SILVA, C. R; PERCEQUILO, A. R.; IACK-XIMENES, G. E.; DE VIVO, M. New distributional records of Blarinomys breviceps (Winge, 1888) (Sigmodontinae, Rodentia). Mammalia, v. 67, p. 147-152, 2003.

SILVEIRA, F. A.; CURE, J. R. High-altitude bee fauna of Southeastern Brazil: implications for biogeographic patterns (Hymenoptera; Apoidea). Studies on Neotropical Fauna and Environment, v. 28, n. 1, p. 47-55, 1993.

SILVEIRA, M. L.; PETTERS, F. B.; JUNG, D. H.; CHRISTOFF, A. U. Registro de Bibimys Massoia, 1979 (Rodentia: Sigmodontinae) no sul do Brasil: Distribuição geográfica e análise morfológica. In: Anais do XII Fórum de Pesquisa da ULBRA. 2012. Disponível em: http://www.conferencias.ulbra. br/index.php/fpu/xiifp/paper/view/390. Acesso em: 10 mai. 2014.

SIKES, R. S.; GANNON, W. L.; AND THE ANIMAL CARE AND USE COMMITTEE OF THE AMERICAN SOCIETY OF MAMMALOGISTS. Guidelines of the American Society of Mammalogists for the use of wild mammals in research. Journal of Mammalogy, v. 92, p. 235-253, 2011.

TALAMONI, S. A.; MOTTA-JUNIOR. J. C.; DIAS, M. M. Fauna de mamíferos da Estação Ecológica de Jataí e da Estação Experimental de Luiz Antônio, São Paulo, Brasil. São Carlos, SP, p. 317-327, 2000. In: SANTOS, J. E.; PIRES, J. S. R. Estudos integrados em ecossistemas, Estação Ecológica de Jataí, v. 1, 2000. 
TETA, P.; PEREIRA, J. A.; MUSCHETTO, E.; FRACASSI, Y. N. Mammalia, Didelphimorphia, Chiroptera, and Rodentia, Parque Nacional Chaco and Capitán Solari, Province of Chaco, Argentina. Check List, v. 5, p. 144-150, 2009.

TETA, P.; PARDIÑAS, U. F. J. Mammalia, Didelphimorphia and Rodentia, central Santa Fe Province, Argentina. Check List, v. 6, p. 552-554, 2010.

UMETSU, F.; NAXARA, L.; PARDINI, R. Evaluating the efficiency of pitfall traps for sampling small mammals in the Neotropics. Journal of Mammalogy, v. 87, p. 757-765, 2006.

WEKSLER, M.; PERCEQUILLO, A. R. Key to the genera of the tribe Oryzomyini (Rodentia: Cricetidae: Sigmodontinae). Mastozoología Neotropical, v. 18, p. 281-292, 2011.

VENTURA, K.; SILVA, M. J. J.; FAGUNDES, V.; CHRISTOFF, A. U.; YONENAGA-YASSUDA, Y. Non-telomeric sites as evidence of chromosomal rearrangement and repetitive (TTAGGG) $n$ arrays in heterochromatic and euchromatic regions in four species of Akodon (Rodentia, Muridae). Cytogenetic and Genome Research, v. 115, p. 169-175, 2006.

VENTURA, K.; SATO-KUWABARA, Y.; FAGUNDES, V.; GEISE, L.; LEITE, Y. L. R.; COSTA, L. P.; SILVA, M. J. J.; YONENAGA-YASSUDA, Y.; RODRIGUES, M. T. Phylogeographic Structure and Karyotypic Diversity of the Brazilian Shrew Mouse (Blarinomys breviceps, Sigmodontinae) in the Atlantic Forest. Cytogenetic and Genome Research, v. 138, p. 19-30, 2012.

VILELA, E. A.; RAMALHO, M. A. P. Análise das temperaturas e precipitações de Lavras, MG. Ciência e Prática, v. 3, p. 71-79, 1979.

VOSS, R. S.; MYERS, P. Pseudoryzomys simplex (Rodentia: Muridae) and the significance of Lund's Collections from the Caves of Lagoa Santa, Brazil. Bulletim American Museum of Natural History, v. 206, p. 414-432, 1991.

ZAMBALDI, L. P.; LOUZADA, J. N. C.; CARVALHO, L. M. T.; SCOLFORO, J. R. S. Análise da vulnerabilidade natural para implantação de unidades de conservação na microrregião da serra de Carrancas, MG. Cerne, v. 17, n. 2, p. 151-159, 2011.

\section{Histórico editorial}

Submetido em: 06/01/2015

Aceito em: 02/06/2015 